\title{
Biochemical markers of time since death in cerebrospinal fluid: a first step towards "Forensomics"
}

Pierre-Antoine Peyron, Sylvain Lehmann, Constance Delaby, Eric Baccino \& Christophe Hirtz

To cite this article: Pierre-Antoine Peyron, Sylvain Lehmann, Constance Delaby, Eric Baccino \& Christophe Hirtz (2019): Biochemical markers of time since death in cerebrospinal fluid: a first step towards "Forensomics", Critical Reviews in Clinical Laboratory Sciences, DOI: 10.1080/10408363.2019.1619158

To link to this article: https://doi.org/10.1080/10408363.2019.1619158

Accepted author version posted online: 15 May 2019.

Submit your article to this journal $₫$

山ll Article views: 35

View Crossmark data ¿ 
Biochemical markers of time since death in cerebrospinal fluid: a first step towards "Forensomics"

Pierre-Antoine Peyron*a,b, Sylvain Lehmann ${ }^{\mathrm{b}}$, Constance Delaby ${ }^{\mathrm{b}}$, Eric Baccino $^{\mathrm{a}}$, Christophe Hirtz

${ }^{a}$ Department of Forensic Medicine, Montpellier University Hospital, Montpellier, France

${ }^{b}$ Laboratory of Biochemistry and Clinical Proteomics, Montpellier University Hospital, Institute for Regenerative Medicine and Biotherapy, Montpellier, France

*Corresponding author:

E-mail address: pa-peyron@chu-montpellier.fr

Telephone number: +33467338586 


\section{Biochemical markers of time since death in cerebrospinal fluid: a first step towards "Forensomics"}

The accurate estimation of the time of death is a challenge in forensic medicine, as the methods routinely used to assess the post-mortem interval (PMI) are far from being precise. Over the past decades, biochemical methods have been implemented on post-mortem samples to improve the precision of PMI estimation. Studies have focussed on the biochemical profiles of closed compartment body fluids, as they are preserved longer than blood after death and are thus subject to confined post-mortem chemical changes. Cerebrospinal fluid (CSF) has been considered a suitable fluid to investigate these changes, as it is found in large amounts and is easy to sample. Moreover, the main molecules found in CSF have known reference values in living subjects, unlike most other body fluids. In this literature review, we focus on the panel of biomarkers that have been studied in CSF based on their potential of offering information on the time of death. The interest of these biomarkers in casework and the research perspectives in this field are discussed. Integrating data from different methods, including biochemistry, for better estimation of the time of death would represent a step forward in the forensic field, paving the way for an innovative approach that we suggest to call "Forensomics".

Keywords: biomarkers; time of death; cerebrospinal fluid; biochemistry; forensic medicine 


\section{Introduction}

One of the most important and challenging tasks in forensic medicine is the estimation of the post-mortem interval (PMI). PMI is defined as the period of time that has elapsed since a person has died, and is thus also called the time since death (TSD). The accurate determination of the PMI is a critical step with obvious medicolegal implications in cases of unwitnessed death. This may be used to establish the timeframe of a crime, to narrow the number of suspects based on their alibi at the time of death, but also to help in identification of a victim in case of a missing person [1-3].

After death, the structure and composition of the human body are considerably altered by a complex series of pathological and biochemical processes [4]. As several of these changes occur sequentially, various methods have been proposed to estimate the TSD based on these processes. In the early PMI, i.e. before the onset of microbial proliferation [5], these methods are mainly based on physical/physicochemical progressive changes, such as body cooling, livor mortis (hypostasis) and rigor mortis. Supravital reactions, including post-mortem excitation-induced reactions of tissues (e.g., mechanical and electrical excitability of skeletal muscle) and pharmacologically induced excitability of the iris, may also be used [6]. Later on, bacterial processes (referred to as putrefaction) and entomology may be considered [6, 7]. These different methods are still routinely used, although they give only imprecise estimates of the PMI. Indeed, they are influenced by a variety of factors that tend to introduce considerable errors, including external (or environmental) factors, such as ambient temperature and humidity, and internal (or endogenous) factors, such as pre-existing diseases, age, or body mass index [3,8,9].

Post-mortem chemistry, also called thanatochemistry, has been introduced in forensic medicine to assist in more precise estimation of the TSD [2] and in providing useful 
information regarding the cause of death $[8,10,11]$. Coe [5] defined forensic chemistry as "one of the more important ancillary procedures for the forensic pathologist". As a result of significant improvements in biochemical techniques, current methods are now able to provide precise, reliable and rapid results as required by the forensic community [2]. Numerous studies have been conducted considering post-mortem chemical changes in a wide variety of biological fluids, including blood, vitreous humor (VH), urine, CSF, pericardial and synovial fluids $[6,7,10,11]$. Some of these changes are due to autolysis (process of cell self-digestion from the activity of endogenous enzymes), while others result from metabolic processes, since the metabolic activities continue in the tissues for variable duration after death $[6,7]$.

Emphasis has been placed on the study of concentration changes of chemicals in closed compartment body fluids, as they are neither altered nor contaminated as quickly as blood after death. Because of their isolated and confined topography, autolysis proceeds more slowly in these fluids than in blood $[3,12,13]$. VH has been the most extensively studied fluid compartment. In particular, the post-mortem increase in potassium concentration in the $\mathrm{VH}$ has been widely investigated for estimating the PMI, but this method has not led to the improvement of the accuracy of the TSD estimation [6,7]. CSF may represent a good alternative to $\mathrm{VH}$ as it is a closed compartment fluid that is found in large volumes and is easy to sample [6,7]. Due to its closeness to the central nervous system (CNS), CSF has also been considered to reflect the changes in the biochemical composition of the brain tissue after death. Contrary to $\mathrm{VH}$, many analytes found in CSF have reference values in living subjects, which make the post-mortem results easier to interpret.

In this paper, we have reviewed the various biochemical compounds that have been studied in CSF as potential biomarkers of the PMI. Studies written in either English or 
French and whose full texts were available online have been included in this review. Book chapters on this topic have also been consulted.

The actual value of these biomarkers in daily forensic practice and the research perspectives in this field are discussed. Integrating data from different methods, including thanatochemistry, could improve TSD estimation through the implementation of an innovative approach that we suggest to call "Forensomics".

\section{Biochemical markers of the post-mortem interval in CSF}

\section{Electrolytes}

\section{a. Potassium}

Mason et al. [14] was the first to find a significant relationship between PMI and potassium levels in cisternal CSF. Many studies have since reported a similar trend [3,13,15-22]. Urban et al. even showed a strong linear correlation between the estimated TSD from cisternal potassium concentration and the estimated TSD based on rectal temperature by using the nomogram method of Henssge [1]. He developed a method for PMI estimation based on cisternal potassium concentration with $98 \%$ confidence limits, but his results have never been able to be reproduced in any other study.

\section{b. Sodium}

Naumann $[16,17]$ was the first to report a slight to moderate decrease of sodium in the CSF after death. This decrease was assumed to be due to autolytic changes of cell membranes resulting in a greater permeability, allowing extracellular ions to diffuse into the cells. Others similarly found a non-significant decrease of sodium with PMI in post-mortem CSF samples [15,20]. More recently, studies showed a statistically significant negative correlation between sodium levels and PMI up to 20-25 h after 
death $[1,3,13,21]$, although the ratio of sodium and potassium concentrations may remain a better parameter for PMI estimation compared to ion values alone [13].

\section{c. Chloride}

Similar to sodium and other predominantly extracellular ions, chloride was shown to decrease in CSF after death in studies by Naumann [16,17], whereas Paulson and Stickney [20] found that they tend to slightly increase with PMI. More recently, Karkela [21] showed a statistically significant post-mortem decrease in chloride levels after death.

\section{d. Calcium}

According to Naumann [16,17], calcium values in post-mortem CSF closely approach those found during life. From 131 post-mortem samples of cisternal fluid, levels of calcium were found to slightly decrease from an ante-mortem value of $5.0 \mathrm{mg} / \mathrm{dL}$ to 4.8 $\mathrm{mg} / \mathrm{dL}$ by $10 \mathrm{~h}$ post-mortem. A relative stability of calcium ions was also reported by others $[3,15,20]$.

\section{e. Magnesium}

Magnesium concentration may tend to increase in CSF after death as a result of its diffusion out of the cells into the extracellular fluid $[16,20]$. However no correlation with the TSD has been shown so far $[1,15]$.

\section{f. Phosphates}

A marked increase of inorganic phosphorus in cisternal CSF after death was noted by Naumann [16,17] and interpreted as evidence of post-mortem esterase activity. The same author found an increase in phosphorus levels from an ante-mortem value of 1.4 $\mathrm{mg} / \mathrm{dL}$ to $8.9 \mathrm{mg} / \mathrm{dL} 10 \mathrm{~h}$ after death [17]. Eliakis et al. [23] stated that TSD could be determined within $3 \mathrm{~h}$ by measurement of CSF inorganic phosphorus, as the increase in phosphorus tends to be linear during that period. Paulson and Stickney [20] also found 
values which tend to be elevated above the normal range for a living patient. According to Schleyer [19], a concentration of inorganic phosphorus exceeding $15 \mathrm{mg} / \mathrm{dL}$ in cisternal CSF may suggest a minimum TSD of $10 \mathrm{~h}$.

\section{g. Bicarbonate}

Naumann [16] reported a slight to moderate post-mortem decrease of bicarbonate with time in cisternal fluid. However, Karkela [21] did not find any statistically significant correlation between these two parameters.

\section{h. Carbon dioxide}

The drop in carbon dioxide concentration in CSF after death has been found to result from post-mortem acidosis [16,20,24], without any correlation with the TSD [20]. Karkela [21] measured the carbon dioxide values in cisternal fluid samples obtained 2, 4, 10 and $24 \mathrm{~h}$ after death, and found carbon dioxide levels to increase 2 to $4 \mathrm{~h}$ after death, then decline.

\section{Carbohydrates}

a. Glucose

In his pioneer work, Naumann described CSF as a better material than blood for postmortem glucose analysis because of the greater reliability of the results obtained in this fluid [24]. He found that glucose was subject to a decrease in CSF after death due to post-mortem glycolysis $[17,24]$. It was assumed that post-mortem values were related to ante-mortem levels and to the cooling rate of the cadaver [20]. A significant correlation between the decrease in glucose and the PMI has also been reported [3,21].

\section{b. Pyruvate}

Only one study found pyruvate to significantly decrease with time in CSF after death [21]. 


\section{c. Lactic acid}

Lactic acid is produced in CSF after death due to local anaerobic metabolism (glycolysis). This lactate increase results in post-mortem acidosis [16,19,20,24]. Postmortem anaerobic glycolytic metabolism was found to proceed at a high rate during the first $10 \mathrm{~h}$ post-mortem. Correspondingly, lactic acid shows its steepest increase within the first 6 to $8 \mathrm{~h}$ after death, with the $\mathrm{pH}$ showing its steepest decrease during the same time interval [5]. Karkela [21] further showed a statistically significant increase in lactate with time up to $24 \mathrm{~h}$ after death.

\section{d. Inositol}

Nixon [25] investigated inositol as a biomarker of PMI and found that post-mortem cisternal fluid contained higher inositol concentrations than lumbar fluid during life. The mean value was more than 10 times that of the mean value from the control group. The rapid rise in the CSF inositol concentration after death was thought to be related to an enzymatic breakdown of a combined form of inositol within the CNS with the subsequent diffusion of free inositol into the CSF. Free inositol contained within the cytoplasm may also diffuse through the cell membrane into the CSF as a result of an increase in membrane permeability due to autolysis. Nixon found a statistical relationship between inositol concentrations and PMI. However, the ranges of concentrations were so wide that it precluded the use of inositol as a means of estimating the PMI. 


\section{Nonprotein nitrogen compounds}

Schleyer [19] showed that TSD may be less than $12 \mathrm{~h}$ if nonprotein nitrogen levels in cisternal fluid are below $50 \mathrm{mg} / \mathrm{dL}$, while it may be less than $24 \mathrm{~h}$ if levels are below 70-80 mg/dL. However, these results have never been confirmed by any further studies.

a. Amino acids

Pucher and Burd [26], Schourup [5] and Schleyer [19] have all demonstrated a rise in free amino acid levels in post-mortem CSF. According to Schleyer [19], amino nitrogen concentrations in cisternal fluid below $14 \mathrm{mg} / \mathrm{dL}$ could mean that death occurred less than $10 \mathrm{~h}$ before. Coe [5] analysed CSF glutamine levels after death and noted a progressive rise in concentrations with an increasing PMI. However, he mentioned that isolated values were difficult to interpret with regard to the TSD. The concentrations of all essential amino acids (phenylalanine, valine, threonine, tryptophan, methionine, leucine, isoleucine, lysine and histidine), in addition to those of glutamate, glutamine, alanine, glycine, proline, aspartate, serine, GABA, cystine, arginine and tyrosine, were found to significantly increase linearly in cisternal fluid 4 to $24 \mathrm{~h}$ after death [21,27]. Girela et al. [28] also attempted to correlate free amino acid concentrations in CSF with the PMI, but the authors did not further evaluate the data due to sample contamination with blood. As noted by Karkela [21], little is known about the pathophysiology of CNS amino acid metabolism in terminal stages of life and in the early PMI, which makes the origin of the different amino acids found in post-mortem CSF difficult to ascertain.

\section{b. Ammonia}

According to Schleyer [19], ammonia concentrations below $2 \mathrm{mg} / \mathrm{dL}$ in cisternal CSF may suggest a maximum TSD of $10 \mathrm{~h}$. Ammonia was subsequently found to significantly increase linearly in cisternal CSF 4 to $24 \mathrm{~h}$ post-mortem [21].

c. Urea 
A post-mortem increase of urea in CSF was reported by Naumann [17,24], whereas Jenkins and Fekete showed urea levels in post-mortem CSF to be closely correlated with ante-mortem blood levels [29,30]. Swain et al. [3] found no statistically significant correlation between PMI and CSF urea concentration.

\section{d. Monoamines}

Endo et al. [31] measured the concentrations of 3,4-dihydroxyphenylacetic acid (DOPAC), homovanillic acid (HVA), 3-methoxy-4-hydroxyphenylglycol (MHPG) and 5-hydroxyindoleacetic acid (5-HIAA) in post-mortem cisternal fluid. They found no relationship between PMI and the levels of HVA, 3-methoxy-4-hydroxyphenylglycol (MHPG) and 5-HIAA, but they showed a significant correlation between PMI and the level of DOPAC, as the possible result of the persistent post-mortem activity of monoamine oxidase (MAO) in brain. However, the large inter-individual variability in DOPAC concentration precluded its use as a measure of the PMI.

Karkela et al. [27] investigated the concentrations of the same four monoamine metabolites in cisternal fluid from 40 cadavers up to $24 \mathrm{~h}$ after death. Levels of 5HIAA, DOPAC, HVA and MHPG were higher in post-mortem samples $2 \mathrm{~h}$ after death than in lumbar fluid in vivo. Furthermore, 5-HIAA concentrations were higher in lumbar fluid than cisternal or ventricular CSF during life at any time after death. DOPAC, HVA, and MHPG concentrations tended to decline with time thereafter, whereas 5-HIAA levels tended to increase up to $10 \mathrm{~h}$ before declining. Nevertheless, the differences between the group means were not statistically significant.

A more recent study by Balbi et al. [32] showed that dopamine and noradrenaline are elevated in post-mortem CSF as compared to CSF from living subjects, with dopamine showing the highest increase. However, he found these increases not to be statistically significant, and wide ranges of concentrations were observed. The same findings were 
reported for serotonin (5-HT) and catecholamines, in line with results from other studies $[33,34]$. A significant correlation between serotonin and TSD was shown by Quan et al. [35].

\section{e. Creatine}

Post-mortem CSF creatine values have been shown to increase after death with regard to length of time $[19,24]$, with a significant inter-individual variability for the same PMI [24]. Nonetheless, Schleyer [19] thought that creatine could serve as a rough indicator of the PMI. He showed that the TSD may not be more than $10 \mathrm{~h}$ if creatine levels in cisternal fluid are less than $5 \mathrm{mg} / \mathrm{dL}$, while it may not be more than $30 \mathrm{~h}$ forlevels lower than $10 \mathrm{mg} / \mathrm{dL}$. Furthermore, Takata et al. [36] found a significant correlation between CSF creatine levels and PMI up to $50 \mathrm{~h}$ post-mortem.

\section{f. Creatinine}

CSF creatinine levels have been found to mirror the blood values after death $[5,17,24,26]$. Naumann $[17,24]$ showed that the post-mortem levels of creatinine in CSF were more than twice as high as those ante-mortem for an average PMI of $10 \mathrm{~h}$, while Jensen found that the concentration of creatinine in CSF increased in parallel with the increment of PMI [5]. Furthermore, Swain et al. [3] reported a significant correlation between post-mortem creatinine levels and PMI, but with wide $95 \%$ confidence limits.

\section{g. Ribonucleosides}

Harkness et al. [37] investigated uridine and inosine as biomarkers of PMI in a few post-mortem CSF samples from newborns. He found a rapid increase within the first hour after death, and to a lesser extent thereafter. 


\section{h. Oxypurines}

\section{i. Uric acid}

Naumann [24] reported higher post-mortem levels of uric acid in CSF than ante-mortem for an average PMI of $6 \mathrm{~h}$, confirming preliminary results from Pucher et al. [26]. In post-mortem CSF samples from newborns, Harkness et al. [37] reported uric acid levels of $70 \mu \mathrm{mol} / \mathrm{L}$ within $1 \mathrm{~h}$ of death, rising to $136 \mu \mathrm{mol} / \mathrm{L}$ during the first day. As for other oxypurines, no significant differences in the uric acid concentration during the first 3 days after death were reported by Manzke et al. [38], but their samples were probably taken too late to show any rapid increase occurring immediately after death [39]. Nevertheless, these authors found a rise in uric acid levels between 1-5 days after death $[5]$.

\section{ii. Xanthine}

Praetorius et al. [40] reported a greater than 100-fold increase in the concentration of xanthine and hypoxanthine during the first $36 \mathrm{~h}$ after death. In newborns, Harkness et al. [37] found mean levels of xanthine to increase from $53 \mu \mathrm{mol} / \mathrm{L}$ in the first hour after death to $73 \mu \mathrm{mol} / \mathrm{L}$ during the first day. Although Manzke et al. [38] did not observe any significant differences in the oxypurine concentrations during the first $72 \mathrm{~h}$ postmortem, they showed an increase in xanthine levels between 1-6 days after death [5].

\section{iii. Hypoxanthine}

Hypoxanthine has been found to rise exponentially in CSF within the early post-mortem period, with the most rapid rise occurring during the first $15 \mathrm{~h}$ post-mortem and equilibration achieved after approximately $20 \mathrm{~h}[1,37,39,40]$. However, Madea et al. [39] showed the $95 \%$ confidence interval to be large and increasing with increasing PMI. No significant post-mortem time-dependent increase was observed by Carpenter et al. in children 1 week to 2 years of age [41]. 


\section{Proteins}

\section{a. Total proteins}

CSF has a low concentration of proteins in healthy individuals, the normal range being 0.20-0.45 g/L [42]. No rise in CSF proteins in the first $24 \mathrm{~h}$ after death was reported by Mangin et al [43]. In contrast, Morihara et al. [44] found a three-fold post-mortem increase with an average PMI of $5.7 \mathrm{~h}$. A significant relationship with PMI was found for longer intervals [45]. Finehout et al. [46] performed a proteomic analysis of both ante- and post-mortem CSF from seven individuals with short PMI (1.5-9.5 h) using two-dimensional gel electrophoresis (2DE) and mass spectrometry: 54 protein spots were identified, showing significantly different intensities between ante- and postmortem CSF. Most of these proteins were intracellular proteins involved in glycolysis or in prevention from oxidative stress, and all but one showed a rise in their spot intensity. This difference in spot intensity was found to be correlated with PMI for 14 proteins.

\section{b. Enzymes}

Paulson et al. [20] reported an increase of beta glucuronidase, acid phosphatase, lactate deshydrogenase $(\mathrm{LDH})$ and creatine kinase $(\mathrm{CK})$ in CSF after death, with no relationship with PMI. In contrast, Osuna et al. [45] found a significant correlation between PMI and CSF concentrations of the two latter enzymes, but also of aldolase and alanine aminotransferase (ALT). However, Osuna et al. studied individuals with significantly longer PMI. With 2DE, Finehout et al. [46] found a 12-fold increase in the intensity of the CK-B spot in post-mortem CSF compared with ante-mortem CSF from the same individual. Karkela [21] found that the concentration of total CK, CK-B, LDH and its isoenzymes 1-3, $\beta$-D-N-acetylglucosaminidase (NAG), and acid phosphatase 
significantly increased linearly with increasing TSD. CK-MB, however, did not show any significant relationship with the TSD across different studies [47-49].

CSF enzymes, including glutamic oxaloacetic transaminase (GOT) [50] and 2',3'cyclic nucleotide 3'-phosphohydrolase (CNP) activity [51] were also studied. GOT concentration increased with an increasing PMI up to $70 \mathrm{~h}$, while a rise in CNP activity was observed in CSF samples collected within $14 \mathrm{~h}$ after death. A subsequent reduction of enzymatic activity was found thereafter, as the result of proteolytic degradation of the enzyme in the CSF and probable lack of further release from the CNS tissue. However, the wide range of the values obtained for both enzymes precluded any accurate assessment of PMI.

c. Albumin

Using bromocresol green dye-binding method, Parmar et al. [52] studied albumin concentration in cisternal fluid samples at different time intervals. He found a significant and linear decrease in albumin levels, but only between $24-72 \mathrm{~h}$ postmortem. These findings are in line with previous studies that showed no correlation between PMI and CSF albumin concentration within the first $24 \mathrm{~h}$ after death [43].

\section{d. Tau protein}

Morihara et al. [44] showed that tau levels in demented and non-demented subjects were more than 30 -fold higher in post-mortem CSF compared with those in antemortem CSF. Tau concentrations were also found to increase with PMI. The postmortem leakage of tau into the CSF was assumed to reflect the same underlying mechanism as in neurodegenerative diseases such as tauopathies (neuronal death). 


\section{e. Cardiac troponins}

Three studies showed that cardiac Troponin $\mathrm{T}$ and $\mathrm{I}$ in cisternal CSF were slightly correlated with PMI up to $48 \mathrm{~h}$ post-mortem [47-49].

\section{f. Myoglobin}

According to one post-mortem investigation, myoglobin in cisternal CSF was found to significantly increase with PMI for various causes of death [48].

\section{g. $S$-100 protein $B$}

S-100 protein B in cisternal CSF showed a moderate time-dependent increase up to 3 days post-mortem for deaths resulting from acute cardiac failure and asphyxia [53], whereas no significant relationship was found between PMI and the protein level in ventricular CSF in suicide and non-suicide cases [34].

\section{Discussion}

The biochemical markers that have been investigated in CSF as potential indicators of PMI are presented in this literature review. Various molecules, such as electrolytes, carbohydrates, nitrogen compounds and proteins, have been studied by means of thanatochemistry in attempts to precisely estimate the TSD, as this estimation still represents a challenge in the forensic field. Unlike post-mortem physical changes whose interpretation is often influenced by subjective judgement [9], biochemical methods have the advantage of being standardised and statistically assessed [2].

CSF has been considered as a suitable fluid compartment to investigate early postmortem chemical changes, as concentration gradients in this fluid are still effective in the first few hours after death [6]. The exploration of some biomarkers may even remain relevant for a few days after death, as their concentrations have been found to change in CSF longer than $72 \mathrm{~h}$ post-mortem $[5,36,38,50,52]$. 
Although some of these biomarkers have shown a statistically significant correlation with PMI (Table 1), their values are often highly variable over PMI, with large 95\% confidence limits and weak correlation coefficients. Hence, most biochemical components in CSF have been considered to be only of limited value for determining the TSD when used singly, having at best a statistical significance.

The inter-individual variability observed in the biochemical profile of the CSF after death is undeniably one of the explanations for these large margins of error. However, the present review has raised various methodological issues that should be considered in order to improve the design of further studies that need to be performed in this field, including the following:

- Many studies lack statistical power and thus potential significance of results due to a small sample size $[18,32,37,46]$.

- Criteria used for selecting participants greatly differ from one study to another, which makes inter-comparison of results obtained for the same biomarker difficult. For example, some studies have included patients with CNS diseases or trauma $[32,46,50]$ while others have not $[3,13,20,52]$. This may greatly affect the results as the post-mortem levels of intracellular biomarkers in the CSF from patients with CNS disorders (such as neurodegenerative disease, stroke or infection) or traumatic brain injury may be subject to an increase due to substantial brain cell death.

- PMI should be inferred from the actual time of death. Instead, time of death is sometimes estimated based on autopsy findings or data obtained from police investigation [31,47-49,53], leading to biased estimates of PMI.

- Factors known to influence post-mortem changes are inconsistently considered. Discrepancies in the results might, for instance, arise from body refrigeration before CSF sampling, as cooling slows autolytic and metabolic processes (e.g. glycolysis). 
However, only a few studies have included corpses stored at ambient temperature before CSF collection [31,52]. This may be partly due to ethical concerns that this methodology could raise in case of bodies left at room temperature for a long time. In some studies in which samples were taken at different TSD, corpses were stored at room temperature in the first hours, then cooled, probably in order to prevent putrefaction $[21,27]$. Like the ambient temperature, the agonal time is also assumed to be an important factor. In slow-death patients, accumulation of lactic acid can lead to massive acidosis that may affect, for instance, CSF concentrations of monoamines or amino acids $[21,27,54]$. The agonal status has, however, only been considered in a few studies $[21,27,43]$.

- The site of CSF collection frequently differs across studies and within the same study. CSF is alternatively withdrawn by lumbar, cisternal or yentricular punctures. Ante-mortem punctures are, in their vast majority, performed in the lumbar region, whereas post-mortem CSF is usually removed from cisternal or ventricular aspirates. However, significant variations in the concentrations of several biochemical parameters have been reported between these sites [55,56]. Reiber [57] found individual protein concentrations in the ventricular region to be up to 3.5-fold higher than those in the lumbar region. A significant rostro-caudal concentration gradient has also been shown for tryptophan, HVA, 5-HT and 5-HIAA [33,58,59]. A recent study showed statistical differences in electrolytes in CSF between the lumbar and the ventricular sites, with the post-mortem samples obtained from the ventricular subarachnoid space having statistically lower sodium and chloride but higher magnesium and potassium [60]. Because of divergent gradients of diffusion, the values obtained from these different sites should not be compared with one another. 
It is assumed that the intracranial fluid would better reflect the subtle biochemical changes occurring in the brain compared to the spinal fluid $[27,60]$.

- Pre-analytical and analytical methodologies vary across studies for the same biomarker, although it is known that there are significant differences among the values obtained according to the particular methodologies used [5]. Such variations may be critical to properly evaluate analytes. For instance, particular attention should be paid to the type of container used to collect and store CSF samples, as the concentration of various components may be affected by the characteristics of the receptacle (e.g. decrease due to adhesion to the tube wall). Furthermore, samples should be frozen as soon as possible after collection (if not processed and analysed immediately), and repeated freeze/thaw cycles should be avoided in order to preserve the stability of the analytes [61]. Various analytical procedures have also been combined in some studies without having previously been compared [50,51] or validated by independent research. Comparing values from different studies requires identical methodologies or at least procedures that are assumed to give comparable results [5]. Indeed, variations may occur between laboratories even when using the same assays. Standardised procedures, similar to those applied to the analysis of the proteins associated with Alzheimer's disease, should be established and implemented to address this point $[62,63]$.

- Post-mortem concentrations are rarely compared with reference values from living persons, although the latter are of interest to interpret post-mortem variations and to determine the minimum time necessary for these changes to occur after death. These reference values (Table 2) are mostly obtained from the literature [16,24,27,64,65] or from control groups $[20,21,44]$. At the individual level, it may be difficult to ascertain that ante-mortem values were comprised within the "normal" range before 
death. Moreover, the broad range of some reference values can also make the interpretation of post-mortem concentration changes difficult, especially in the early PMI. To our knowledge, only one study compared ante- and post-mortem values from the same patients, although the samples were collected from two distinct sites [46].

- There is a lack of kinetic studies assessing the time dependence of biomarkers at the individual level, by means of repeated samples performed at different times after death in the same person. Therefore post-mortem fluctuations in the concentrations of most biomarkers over time are not currently known.

- In regard to statistical analysis, most studies do not provide clear data on the precision of methods used. Many authors only consider mean values of the correlation between concentrations of the studied parameter(s) and the TSD or correlation coefficients. Instead, there is a need to refer to statistical parameters of the deviation of single values from the mean correlation, such as confidence limits [1]. It should also be noted that no comparison of the precision of new methods with that of standard methods for estimating PMI could be found in most studies that have been reviewed.

Overall, several factors contribute to the fact that to date, no single CSF parameter has been found to enhance the accuracy and the reliability of PMI estimation. If interindividual variability is inevitable, following a strict study design could help address most methodological issues discussed above. Madea [6] established several criteria that an estimation method for TSD should meet to be of highest evidence value:

- The method must have been investigated in longitudinal studies on wellcharacterized samples; 
- The method must rely on a mathematical description of the post-mortem change(s) studied and provide a quantitative measurement;

- Influencing factors governing the change of the studied parameter(s) must be quantitatively taken into account, such as ambient temperature and agonal time;

- Clear data on the method precision must be available, with calculation of mean values and confidence limits. It must then be compared with those of standard methods, at the same PMI, to check for improvement.

- The precision and the reliability of the method must be determined using independent case material, including different causes of death, pre-existing diseases and agonal periods;

- The method should have been tested through field studies to check its practical applicability.

When dealing with chemical-based methods, particular attention should also be given to the standardisation of the pre-analytical and analytical procedures, and the post-mortem concentration changes of biomarkers should be assessed by means of kinetic studies in the same individual.

To date, only a few methods have fulfilled Madea's guidelines: the temperature-based methods of Henssge [7,66-70] and Baccino [71,72], as well as various approaches based on potassium concentration in $\mathrm{VH}$ [6]. As these latter have not led to a significant improvement of PMI estimation, both methods based on body cooling still remain the most simple, precise and reliable procedures for TSD estimation. Nevertheless, the resulting estimation has, at best, an interval of a few hours around the mean value with these methods. 
Improving the precision of PMI by means of thanatochemistry represents a challenging task in the forensic field. Some chemical parameters that were investigated decades ago with traditional analytical methods may hold potential value in estimating the TSD, but have not been further studied by adequate and newer methodologies on larger cohorts since. Thus, attention should now be focused on performing well-designed studies instead of necessarily looking for new biomarkers. As stated by Camps [73], "our aim should be to obtain a figure with as small a margin of error as possible”.

Recent developments in biochemical methodologies and techniques now provide the opportunity to analyse multiple biomarkers at once within a short time, based on a multiplex approach [2]. This is of interest as it is very unlikely that the measurement of a single parameter will provide a completely reliable estimate of PMI in the future. Instead, it has been suggested that a combination of chemical determinations may be helpful in estimating the TSD, particularly in the early PMI $[2,8]$. The focus should be placed on biomarkers whose post-mortem increase is solely the result of diffusion, rather than on parameters that increase in response to metabolic processes [1]. Data from thanatochemistry could then be used together with those provided by scientifically-validated methods by performing a multiple linear regression analysis, for a common result of death time estimation, in an attempt to narrow down the confidence limits and increase the reliability of the estimation of PMI [74].

In the same way as it has been suggested to combine methods based on supravital processes with predominantly physical methods such as Henssge's nomogram for estimating the TSD in casework [1], we further propose to integrate data from thanatochemistry in an innovative and holistic "forensomic" approach, in reference to "omics sciences" [75]. Consideration of such data has already been shown to be relevant in the determination of the cause of death $[10,11]$. To the best of our 
knowledge, the only author who assessed the combination of physical and biochemical methods for the estimation of TSD obtained a high correlation between death time estimation from cisternal potassium and body temperature [1]. However, further studies are necessary because of discrepancies between his results and those from subsequent research.

\section{Conclusion}

For the last decades, many biochemical parameters have been studied in post-mortem CSF as potential biomarkers of TSD. Their single value remains limited in practice, since these parameters lack precision and reliability for estimating TSD. However, biochemical markers still remain of great interest for research purposes, as thanatochemistry could eventually assist in more precise estimation of the interval since death in the future.

Current biochemical techniques have the potential to open up some interesting horizons, as they are more sensitive and specific than traditional ones and allow high throughput approaches. They provide the opportunity for some biochemical markers that have previously been investigated to be "revisited" by means of the most recent technological developments, and for some potential biomarkers never considered before to be identified.

These new methodologies should be implemented in well-conducted, unbiased field studies complying with the aforementioned criteria. Combining the most accurate chemical-based methods with current standard procedures would pave the way for an integrated approach that we suggest to call "Forensomics", that could ultimately 
provide sufficient certainty for a reliable medicolegal statement regarding PMI estimation.

\section{Disclosure of interest}

The authors report no conflict of interest.

\section{References}

[1] Madea B. Estimation of the Time Since Death, 3rd Edition. Boca Raton, (FL): CRC Press; 2015.

[2] Donaldson AE, Lamont IL. Estimation of post-mortem interval using biochemical markers. Aust. J. Forensic Sci. 2014;46:8-26.

[3] Swain R, Kumar A, Sahoo J, et al. Estimation of post-mortem interval: A comparison between cerebrospinal fluid and vitreous humour chemistry. J. Forensic Leg. Med. 2015;36:144-148.

[4] Zhou C, Byard RW. Factors and processes causing accelerated decomposition in human cadavers - An overview. J. Forensic Leg. Med. 2011;18:6-9.

[5] Coe JI. Postmortem chemistry update. Emphasis on forensic application. Am. J. Forensic Med. Pathol. 1993;14:91-117.

[6] Madea B. Methods for determining time of death. Forensic Sci. Med. Pathol. 2016;12:451-485. 
[7] Madea B. Is there recent progress in the estimation of the postmortem interval by means of thanatochemistry? Forensic Sci. Int. 2005;151:139-149.

[8] Henry JB, Smith FA. Estimation of the postmortem interval by chemical means. Am. J. Forensic Med. Pathol. 1980;1:341-347.

[9] Wyler D, Marty W, Bär W. Correlation between the post-mortem cell content of cerebrospinal fluid and time of death. Int. J. Legal Med. 1994;106:194-199.

[10] Palmiere C, Mangin P. Postmortem chemistry update part I. Int. J. Legal Med. 2012;126:187-198.

[11] Palmiere C, Mangin P. Postmortem chemistry update part II. Int. J. Legal Med. 2012;126:199-215.

[12] Arroyo A, Rosel P, Marron T. Cerebrospinal fluid: postmortem biochemical study. J. Clin. Forensic Med. 2005;12:153-156.

[13] Yadav J, Deshpande A, Arora A, et al. Estimation of time since death from CSF electrolyte concentration in Bhopal region of central India. Leg. Med. Tokyo Jpn. 2007;9:309-313.

[14] Mason JK, Klyne W, Lennox B. Potassium Levels in the Cerebrospinal Fluid after Death. J. Clin. Pathol. 1951;4:231-233.

[15] Murray E. Potassium levels in cerebrospinal fluid and their relation to duration of death. J Forensic Sci. 1958;3:480-485.

[16] Naumann HN. Cerebrospinal fluid electrolytes after death. Proc. Soc. Exp. Biol. Med. 1958;98:16-18. 
[17] Naumann HN. Postmortem chemistry of the vitreous body in man. Arch. Ophthalmol. 1959;62:356-363.

[18] Fraschini F, Muller E, Zanoboni A. Post-mortem increase of potassium in human cerebrospinal fluid. Nature. 1963;198:1208.

[19] Schleyer F. Methods of Forensic Science, vol. 2. New York (NY): John Wyley and Sons; 1963.

[20] Paulson GW, Stickney D. Cerebrospinal fluid after death. Confin. Neurol. 1971;33:149-162.

[21] Kärkelä JT. Critical evaluation of postmortem changes in human autopsy cisternal fluid. Enzymes, electrolytes, acid-base balance, glucose and glycolysis, free amino acids and ammonia. Correlation to total brain ischemia. J. Forensic Sci. 1993;38:603-616.

[22] Eliakis E, Eliakis A, Coutselinis A. Fluctuations des électrolytes du liquide céphalo-rachidien après la mort et leur signification pour la détermination du moment du décès. Ann. Méd. lég. 1966;108-111.

[23] Eliakis E, Eliakis A, Coutselinis A. Détermination de l'heure de la mort par le dosage du phosphore inorganique du liquide cérébro-spinal. Ann. Méd. lég. $1965 ; 366-371$.

[24] Naumann HN. Studies on Postmortem Chemistry. Am. J. Clin. Pathol. 1950;20:314-324.

[25] Nixon DA. Cerebrospinal fluid inositol and its rise in post-mortem specimens. J. Physiol. 1955;129:272-280. 
[26] Pucher G, Burd L. A preliminary study of the chemistry of postmortem blood and spinal fluid. Bull Buffalo Gen Hosp. 1925;11-13.

[27] Kärkelä J, Scheinin M. Tryptophan and biogenic amine metabolites in postmortem human cisternal fluid: effects of post-mortem interval and agonal time. J. Neurol. Sci. 1992;107:239-245.

[28] Girela E, Villanueva E, Irigoyen P, et al. Free amino acid concentrations in vitreous humor and cerebrospinal fluid in relation to the cause of death and postmortem interval. J. Forensic Sci. 2008;53:730-733.

[29] Jenkins WJ. The Significance of Blood and Cerebrospinal Fluid Urea Levels Estimated after Death. J. Clin. Pathol. 1953;6:110-113.

[30] Fekete JF, Brunsdon DFV. The Use of Routine Laboratory Tests in Postmortem Examinations. Can. Soc. Forensic Sci. J. 1974;7:238-254.

[31] Endo T, Hara S, Kuriiwa F, et al. Postmortem changes in the levels of monoamine metabolites in human cerebrospinal fluid. Forensic Sci. Int. 1990;44:61-68.

[32] Balbi T, Fusco M, Vasapollo D, et al. The presence of trace amines in postmortem cerebrospinal fluid in humans. J. Forensic Sci. 2005;50:630-632.

[33] Musshoff F, Menting T, Madea B. Postmortem serotonin (5-HT) concentrations in the cerebrospinal fluid of medicolegal cases. Forensic Sci. Int. 2004;142:211219. 
[34] Dogan KH, Unaldi M, Demirci S. Evaluation of Postmortem Cerebrospinal Fluid S100B Protein and Serotonin Levels: Comparison of Suicidal Versus Nonsuicidal Deaths in Konya, Turkey. J. Forensic Sci. 2016;61:1285-1291.

[35] Quan L, Ishikawa T, Hara J, et al. Postmortem serotonin levels in cerebrospinal and pericardial fluids with regard to the cause of death in medicolegal autopsy. Leg. Med. Tokyo Jpn. 2011;13:75-78.

[36] Takata T, Kitao T, Miyaishi S. Relationship between post-mortem interval and creatine concentration in vitreous humour and cerebrospinal fluid. Aust $\mathrm{J}$ Forensic Sci. 2014;46:160-165.

[37] Harkness RA, Lund RJ. Cerebrospinal fluid concentrations of hypoxanthine, xanthine, uridine and inosine: high concentrations of the ATP metabolite, hypoxanthine, after hypoxia. J. Clin. Pathol. 1983;36:1-8.

[38] Manzke H, Krämer M, Dörner K. Post-mortem oxypurine concentrations in the CSF. Adv. Exp. Med. Biol. 1986;195 Pt A:587-591.

[39] Madea B, Käferstein H, Hermann N, et al. Hypoxanthine in vitreous humor and cerebrospinal fluid--a marker of postmortem interval and prolonged (vital) hypoxia? Remarks also on hypoxanthine in SIDS. Forensic Sci. Int. 1994;65:1931.

[40] Praetorius E, Poulsen H, Dupont H. Uric acid, xanthine and hypoxanthine in the cerebrospinal fluid. Scand. J. Clin. Lab. Invest. 1957;9:133-137. 
[41] Carpenter KH, Bonham JR, Worthy E, et al. Vitreous humour and cerebrospinal fluid hypoxanthine concentration as a marker of pre-mortem hypoxia in SIDS. J. Clin. Pathol. 1993;46:650-653.

[42] Morris JA, Harrison LM, Telford DR. Postmortem cerebrospinal fluid pleocytosis: a marker of inflammation or postmortem artifact? Int. J. Pediatr. 2012;2012:964074.

[43] Mangin P, Lugnier AA, Chaumont AJ, et al. Forensic significance of postmortem estimation of the blood cerebrospinal fluid barrier permeability. Forensic Sci. Int. 1983;22:143-149.

[44] Morihara T, Kudo T, Ikura Y, et al. Increased tau protein level in postmortem cerebrospinal fluid. Psychiatry Clin. Neurosci. 1998;52:107-110.

[45] Osuna E, Perez-Carceles MD, Luna A, et al. Efficacy of cerebro-spinal fluid biochemistry in the diagnosis of brain insult. Forensic Sci. Int. 1992;52:193-198.

[46] Finehout EJ, Franck Z, Relkin N, et al. Proteomic analysis of cerebrospinal fluid changes related to postmortem interval. Clin. Chem. 2006;52:1906-1913.

[47] Maeda H, Michiue T, Zhu B-L, et al. Analysis of cardiac troponins and creatine kinase MB in cerebrospinal fluid in medicolegal autopsy cases. Leg. Med. Tokyo Jpn. 2009;11 Suppl 1:S266-268.

[48] Wang Q, Michiue T, Ishikawa T, et al. Combined analyses of creatine kinase MB, cardiac troponin I and myoglobin in pericardial and cerebrospinal fluids to investigate myocardial and skeletal muscle injury in medicolegal autopsy cases. Leg. Med. Tokyo Jpn. 2011;13:226-232. 
[49] Chen J-H, Inamori-Kawamoto O, Michiue T, et al. Cardiac biomarkers in blood, and pericardial and cerebrospinal fluids of forensic autopsy cases: A reassessment with special regard to postmortem interval. Leg. Med. Tokyo Jpn. $2015 ; 17: 343-350$.

[50] Dito WR. Transaminase activity in postmortem cerebrospinal fluid. Am. J. Clin. Pathol. 1964;42:360-363.

[51] Fan K. 2', 3'-cyclic nucleotide 3'-phosphohydrolase activity in postmortem human spinal fluids. Neurosci. Lett. 1980;19:229-233.

[52] Parmar AK, Menon SK. Estimation of postmortem interval through albumin in CSF by simple dye binding method. Sci. Justice. 2015;55:388-393.

[53] Li D-R, Michiue T, Zhu B-L, et al. Evaluation of postmortem S100B levels in the cerebrospinal fluid with regard to the cause of death in medicolegal autopsy. Leg. Med. Tokyo Jpn. 2009;11 Suppl 1:S273-275.

[54] Wester P, Bateman DE, Dodd PR, et al. Agonal status affects the metabolic activity of nerve endings isolated from postmortem human brain. Neurochem. Pathol. 1985;3:169-180.

[55] Sommer JB, Gaul C, Heckmann J, et al. Does lumbar cerebrospinal fluid reflect ventricular cerebrospinal fluid? A prospective study in patients with external ventricular drainage. Eur. Neurol. 2002;47:224-232.

[56] Weisner B, Bernhardt W. Protein fractions of lumbar, cisternal, and ventricular cerebrospinal fluid. Separate areas of reference. J. Neurol. Sci. 1978;37:205-214. 
[57] Reiber H. Dynamics of brain-derived proteins in cerebrospinal fluid. Clin. Chim. Acta. 2001;310:173-186.

[58] Young SN, Garelis E, Lal S, et al. Tryptophan and 5-hydroxyindoleacetic acid in human cerebrospinal fluid. J. Neurochem. 1974;22:777-779.

[59] Nordin C, Siwers B, Bertilsson L. Site of lumbar puncture influences levels of monoamine metabolites. Arch. Gen. Psychiatry. 1982;39:1445.

[60] Garland J, Philcox W, Kesha K, et al. Differences in Sampling Site on Postmortem Cerebrospinal Fluid Biochemistry: A Preliminary Study. Am. J. Forensic Med. Pathol. 2018;39:304-308.

[61] Schoonenboom NSM, Mulder C, Vanderstichele H, et al. Effects of processing and storage conditions on amyloid beta (1-42) and tau concentrations in cerebrospinal fluid: implications for use in clinical practice. Clin. Chem. 2005;51:189-195.

[62] Mattsson N, Andreasson U, Persson S, et al. CSF biomarker variability in the Alzheimer's Association quality control program. Alzheimers Dement. $2013 ; 9: 251-261$

[63] Teunissen CE, Verwey NA, Kester MI, et al. Standardization of Assay Procedures for Analysis of the CSF Biomarkers Amyloid $\beta((1-42))$, Tau, and Phosphorylated Tau in Alzheimer's Disease: Report of an International Workshop. Int. J. Alzheimers Dis. 2010;2010.

[64] Wu A. Tietz Clinical Guide to Laboratory Tests. 4th edition. St. Louis, (MO): Saunders; 2006. 
[65] Sjögren M, Vanderstichele H, Agren H, et al. Tau and Abeta42 in cerebrospinal fluid from healthy adults 21-93 years of age: establishment of reference values. Clin. Chem. 2001;47:1776-1781.

[66] Henssge C. Death time estimation in case work. I. The rectal temperature time of death nomogram. Forensic Sci. Int. 1988;38:209-236.

[67] Henssge C, Madea B, Gallenkemper E. Death time estimation in case work. II. Integration of different methods. Forensic Sci. Int. 1988;39:77-87.

[68] Henssge C. Rectal temperature time of death nomogram: dependence of corrective factors on the body weight under stronger thermic insulation conditions. Forensic Sci. Int. 1992;54:51-66.

[69] Henssge C, Althaus L, Bolt J, et al. Experiences with a compound method for estimating the time since death. I. Rectal temperature nomogram for time since death. Int. J. Legal Med. 2000;113:303-319.

[70] Henssge C, Althaus L, Bolt J, et al. Experiences with a compound method for estimating the time since death. II. Integration of non-temperature-based methods. Int. J. Legal Med. 2000;113:320-331.

[71] Baccino E, Martin LDS, Schuliar Y, et al. Outer ear temperature and time of death. Forensic Sci. Int. 1996;83:133-146.

[72] Cattaneo C, Di Giancamillo A, Campari O, et al. Infrared tympanic thermography as a substitute for a probe in the evaluation of ear temperature for post-mortem interval determination: a pilot study. J. Forensic Leg. Med. 2009;16:215-217. 
[73] Camps F. Establishment of the time of death - a critical assessment. J Forensic Sci. $1959 ; 4: 73-82$.

[74] Madea B. Estimation of the Time Since Death. In: Siegel JA, Saukko PJ, editors. Encyclopedia of Forensic Sciences. Waltham: Academic Press; 2013. p. 229-238.

[75] Boja ES, Kinsinger CR, Rodriguez H, et al. Integration of omics sciences to advance biology and medicine. Clin. Proteomics. 2014;11:45. 
Table 1. Summary of the studies reporting a statistically significant correlation between

biochemical markers in CSF and PMI.

\begin{tabular}{|c|c|c|c|c|c|c|c|c|}
\hline Parameter & $\begin{array}{l}\text { Number } \\
\text { of cases }\end{array}$ & $\begin{array}{l}\text { Characteristics of the study } \\
\text { population }\end{array}$ & Refrigeration & $\begin{array}{l}\text { Puncture } \\
\text { site }\end{array}$ & PMI & $\begin{array}{l}\text { Analytical } \\
\text { method }\end{array}$ & $\begin{array}{l}\text { Concentratio } \\
\text { n change } \\
\text { with PMI }\end{array}$ & Reference \\
\hline \multirow[t]{4}{*}{ Potassium } & 46 & $\begin{array}{l}\text { Bodies randomly selected at the } \\
\text { mortuary, exclusion of } \\
\text { meningeal disease and diseases } \\
\text { likely to disturb the serum } \\
\text { potassium level }\end{array}$ & N/A & Cisternal & $\begin{array}{l}1.5-70 \mathrm{~h}, \\
\text { punctures at } \\
\text { different PMI in } \\
\text { eight cases }\end{array}$ & $\begin{array}{l}\text { Flame } \\
\text { photometry }\end{array}$ & Increase & [14] \\
\hline & 40 & $\begin{array}{l}\text { Autopsy cases, natural deaths } \\
\text { except for one case } \\
\text { (intoxication), no known } \\
\text { neurological disorder }\end{array}$ & $\begin{array}{l}\text { For the } 10 \text { and } \\
24 \mathrm{~h} \text { groups }\end{array}$ & Cisternal & $\begin{array}{l}4 \text { groups: } 2,4,10 \\
\text { and } 24 \mathrm{~h}\end{array}$ & $\begin{array}{l}\text { Ion- } \\
\text { selective } \\
\text { methodrode }\end{array}$ & Increase & [21] \\
\hline & 100 & $\begin{array}{l}\text { Autopsy cases, serum } \\
\text { electrolyte levels assumed to be } \\
\text { normal at the time of death, } \\
\text { head trauma and brain } \\
\text { pathology excluded }\end{array}$ & N/A & Ventricular & $\begin{array}{l}4 \text { groups: } 0-6 \mathrm{~h} ; 6- \\
12 \mathrm{~h} ; 12-18 \mathrm{~h} ;>18\end{array}$ & $\begin{array}{l}\text { Flame } \\
\text { photometry }\end{array}$ & Increase & [13] \\
\hline & 100 & $\begin{array}{l}\text { Autopsy cases, meningitis, } \\
\text { encephalitis, } \\
\text { septic shock and intracranial } \\
\text { haemorrhage excluded }\end{array}$ & & Cisternal & $4.5-78.5 \mathrm{~h}$ & $\begin{array}{l}\text { Ion- } \\
\text { selective } \\
\text { electrode } \\
\text { method }\end{array}$ & Increase & [3] \\
\hline \multirow{2}{*}{ Sodium } & 100 & $\begin{array}{l}\text { Autopsy cases, serum } \\
\text { electrolyte levels assumed to be } \\
\text { normal at the time of death, } \\
\text { head trauma and brain } \\
\text { pathology excluded }\end{array}$ & N/A & Ventricular & $\begin{array}{l}4 \text { groups: 0-6 h; 6- } \\
12 \mathrm{~h} ; 12-18 \mathrm{~h} ;>18 \\
\mathrm{~h}\end{array}$ & $\begin{array}{l}\text { Flame } \\
\text { photometry }\end{array}$ & Decrease & [13] \\
\hline & 100 & $\begin{array}{l}\text { Autopsy cases, meningitis, } \\
\text { encephalitis, } \\
\text { septic shock and intracranial }\end{array}$ & For long PMI & Cisternal & $4.5-78.5 \mathrm{~h}$ & $\begin{array}{l}\text { Ion- } \\
\text { selective } \\
\text { electrode }\end{array}$ & Decrease & [3] \\
\hline
\end{tabular}




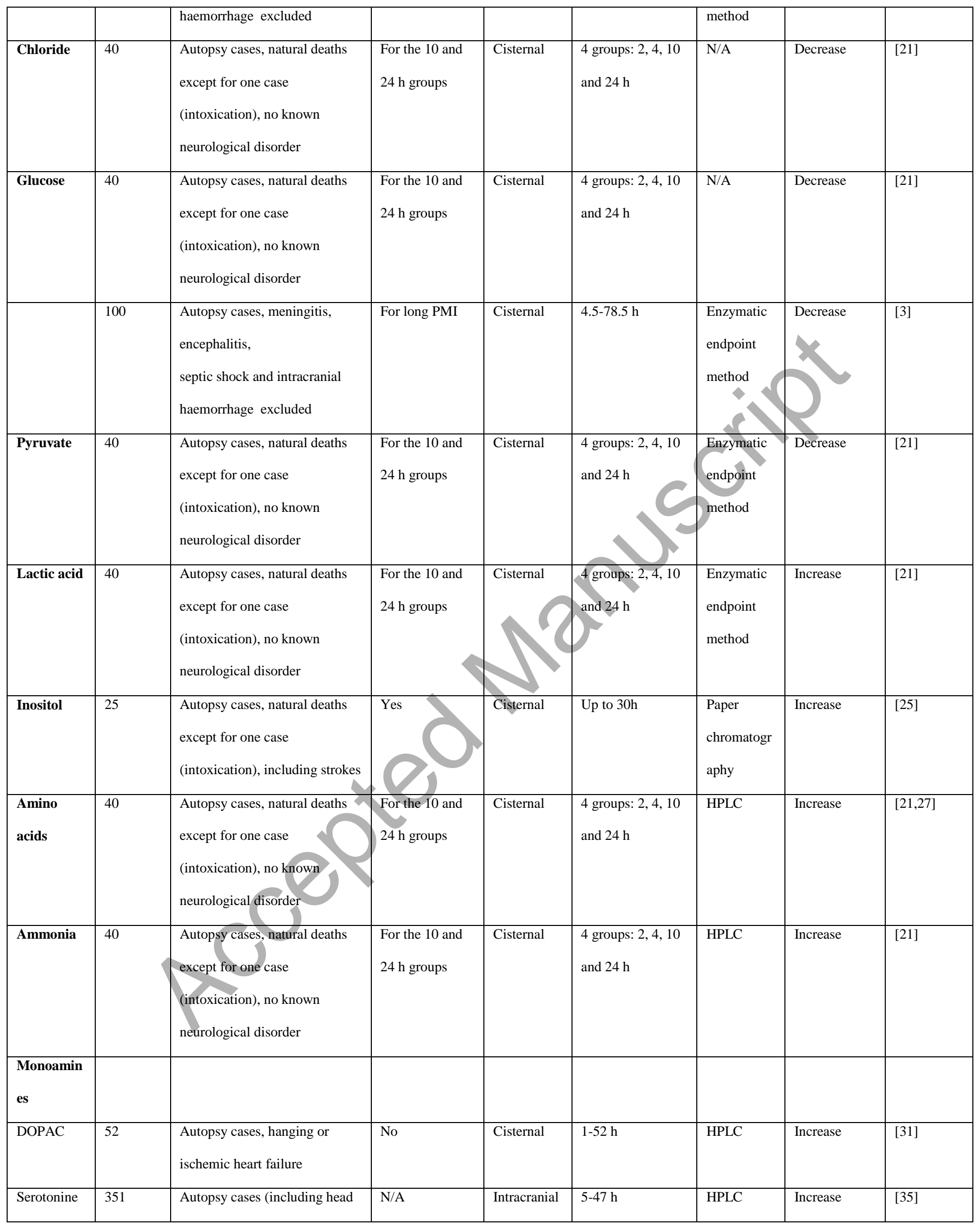




\begin{tabular}{|c|c|c|c|c|c|c|c|c|}
\hline & & $\begin{array}{l}\text { injury and cerebrovascular } \\
\text { disease) }\end{array}$ & & & & & & \\
\hline Creatinine & 100 & $\begin{array}{l}\text { Autopsy cases, meningitis, } \\
\text { encephalitis, } \\
\text { septic shock and intracranial } \\
\text { haemorrhage excluded }\end{array}$ & For long PMI & Cisternal & $4.5-78.5 \mathrm{~h}$ & $\begin{array}{l}\text { Jaffe's } \\
\text { method }\end{array}$ & Increase & [3] \\
\hline $\begin{array}{l}\text { Total } \\
\text { proteins }\end{array}$ & 34 & $\begin{array}{l}\text { Autopsy cases, various causes } \\
\text { of death (including head } \\
\text { trauma) }\end{array}$ & N/A & Cisternal & $\begin{array}{l}41.1-51.5 \mathrm{~h} \text { on } \\
\text { average } \\
\text { (depending on the } \\
\text { groups) }\end{array}$ & $\begin{array}{l}\text { Bradford's } \\
\text { method }\end{array}$ & Increase & [45] \\
\hline \multicolumn{9}{|l|}{ Enzymes } \\
\hline LDH & 34 & $\begin{array}{l}\text { Autopsy cases, various causes } \\
\text { of death (including head } \\
\text { trauma) }\end{array}$ & N/A & Cisternal & $\begin{array}{l}41.1-51.5 \mathrm{~h} \text { on } \\
\text { average } \\
\text { (depending on the } \\
\text { groups) }\end{array}$ & $\begin{array}{l}\text { UV } \\
\text { spectrophot } \\
\text { ometry, } \\
\text { commercial } \\
\text { kits }\end{array}$ & Increase & [45] \\
\hline \multicolumn{9}{|l|}{ Aldolase } \\
\hline Albumin & 100 & $\begin{array}{l}\text { Autopsy cases, various causes } \\
\text { of death, head trauma excluded }\end{array}$ & No & Cisternal & $2-72 \mathrm{~h}$ & $\begin{array}{l}\text { BCG dye- } \\
\text { binding } \\
\text { method }\end{array}$ & Decrease & [52] \\
\hline $\begin{array}{l}\text { cTnI, } \\
\text { cTnT }\end{array}$ & 257 & $\begin{array}{l}\text { Autopsy cases, various causes } \\
\text { of death (including head trauma } \\
\text { and strokes) }\end{array}$ & N/A & Cisternal & $4-48 \mathrm{~h}$ & $\begin{array}{l}\text { RPIA } \\
(\mathrm{cTnI}) \\
\text { ECL } \\
(\mathrm{cTnT})\end{array}$ & Increase & {$[47]$} \\
\hline \multirow[t]{3}{*}{ Myoglobin } & 295 & $\begin{array}{l}\text { Autopsy cases, various causes } \\
\text { of death (including head trauma } \\
\text { and strokes) }\end{array}$ & N/A & Cisternal & $5-46 \mathrm{~h}$ & $\begin{array}{l}\text { RPIA } \\
(\mathrm{cTnI}) \\
\begin{array}{l}\text { ECL } \\
(\mathrm{cTnT})\end{array}\end{array}$ & Increase & {$[48]$} \\
\hline & 1923 & $\begin{array}{l}\text { Autopsy cases, various causes } \\
\text { of death (including head trauma } \\
\text { and strokes) }\end{array}$ & N/A & Cisternal & $3-48 \mathrm{~h}$ & $\begin{array}{l}\text { RPIA } \\
(\mathrm{cTnI}) \\
\text { ECL } \\
(\mathrm{cTnT})\end{array}$ & Increase & {$[49$} \\
\hline & 295 & $\begin{array}{l}\text { Autopsy cases, various causes } \\
\text { of death (including head trauma } \\
\text { and strokes) }\end{array}$ & N/A & Cisternal & $5-46 \mathrm{~h}$ & RPIA & Increase & [48] \\
\hline
\end{tabular}




\begin{tabular}{|l|l|l|l|l|l|l|l|}
\hline $\begin{array}{l}\text { S-100 } \\
\text { protein B }\end{array}$ & 216 & $\begin{array}{l}\text { Autopsy cases, various causes } \\
\text { of death (including head } \\
\text { trauma) }\end{array}$ & N/A & Cisternal & Up to 3 days & ELISA & Increase \\
& & & [53] & \\
\hline
\end{tabular}

$2 D E$ two-dimensional gel electrophoresis, $A L T$ alanine aminotransferase, $B C G$ bromocresol green, $C K$ creatine kinase, $c T n I$ cardiac troponin I, $c T n T$ cardiac troponin T, DOPAC 3,4-dihydroxyphenylacetic acid, ECL electro-chemiluminescence immunoassay, ELISA enzyme-linked immunosorbent assay, HPLC highperformance liquid chromatography, $L D H$ lactate deshydrogenase, $M S$ mass spectrometry, $N / A$ not available, $N A G \beta$-D-N-acetylglucosaminidase, $P M I$ postmortem interval, RPIA radial partition immunoassay, $U V$ ultraviolet 
Table 2. Reference values of various biochemical parameters in lumbar CSF in adults.

\begin{tabular}{|c|c|c|}
\hline Parameter & Range of values & Reference \\
\hline Potassium & $2.5-3.7 \mathrm{mmol} / \mathrm{L}$ & {$[16]$} \\
\hline Sodium & $134-152 \mathrm{mmol} / \mathrm{L}$ & {$[16]$} \\
\hline Chloride & $119-128 \mathrm{mmol} / \mathrm{L}$ & {$[16]$} \\
\hline Calcium & $1.1-1.3 \mathrm{mmol} / \mathrm{L}$ & {$[16]$} \\
\hline Magnesium & $0.85-1.1 \mathrm{mmol} / \mathrm{L}$ & {$[16]$} \\
\hline Phosphates & $0.29-0.65 \mathrm{mmol} / \mathrm{L}$ & {$[16]$} \\
\hline Bicarbonate & $25-28 \mathrm{mmol} / \mathrm{L}$ & {$[64]$} \\
\hline Glucose & $2.2-3.9 \mathrm{mmol} / \mathrm{L}$ & {$[64]$} \\
\hline Lactic acid & $1.1-2.4 \mathrm{mmol} / \mathrm{L}$ & {$[24]$} \\
\hline Urea & $1.3-4.7 \mathrm{mmol} / \mathrm{L}$ & {$[27]$} \\
\hline \multirow{5}{*}{ DHIAA } & $86-215 \mathrm{nmol} / \mathrm{L}$ & {$[27]$} \\
\hline DOPAC & $0.43-14.6 \mathrm{nmol} / \mathrm{L}$ & {$[27]$} \\
\hline HVA & $158-428 \mathrm{nmol} / \mathrm{L}$ & {$[27]$} \\
\hline MHPG & $25-48 \mathrm{nmol} / \mathrm{L}$ & {$[24]$} \\
\hline Creatinine & $44-106 \mu \mathrm{mol} / \mathrm{L}$ & {$[24]$} \\
\hline Uric acid & $23-166 \mu \mathrm{mol} / \mathrm{L}$ & {$[64]$} \\
\hline Total proteins & $0.15-0.45 \mathrm{~g} / \mathrm{L}$ & {$[65]$} \\
\hline \multirow{2}{*}{ Tau protein } & $<300 \mathrm{ng} / \mathrm{L}(21-50 \mathrm{yr})$ & {$[500 \mathrm{ng} / \mathrm{L}(51-70 \mathrm{yr})$} \\
\hline
\end{tabular}

DOPAC 3,4-dihydroxyphenylacetic acid, 5-HIAA 5-hydroxyindoleacetic acid, $H V A$ homovanillic acid, $M H P G$ 3-methoxy-4-

hydroxyphenylglycol 